\title{
Immunoglobulin abnormalities and monoclonal gammopathy of undetermined significance in uninfected and HIV-infected men
}

\author{
Elizabeth Crabb Breen ${ }^{1 *}$, Jerry Katzmann², Robert Kyle ${ }^{2}$, Roger Detels ${ }^{3}$ \\ From $12^{\text {th }}$ International Conference on Malignancies in AIDS and Other Acquired Immunodeficiencies \\ (ICMAOI) \\ Bethesda, MD, USA. 26-27 April, 2010
}

\section{Background}

Multiple myeloma (MM) is a non-AIDS related malignancy of an immunoglobulin (Ig)-secreting B cell (plasma cell) usually associated with older age. MM is characterized by the presence of a high concentration monoclonal Ig protein in serum, and excretion of free light chains (FLC) in urine. In the years preceding MM diagnosis, a small monoclonal Ig develops that may be detectable upon serum protein electrophoresis, resulting in a premalignant condition known as monoclonal gammopathy of undetermined significance (MGUS). In an individual with MGUS, there may also be abnormal levels of FLC. Increased circulating levels of Ig, other indicators of B cell hyperactivation, and B cell lymphoma are well-recognized features of HIV infection. There have also been several reports of increased prevalence of MGUS and a meta-analysis showing increased risk of MM among HIV-infected (HIV+) individuals. There are, however, little or no longitudinal data on HIV-associated Ig abnormalities, B cell activation, and MGUS. We have initiated a pilot study within the Multicenter AIDS Cohort Study (MACS), a prospective study of untreated and treated HIV infection and AIDS in the United States, to begin to examine Ig abnormalities associated with MGUS in HIV-uninfected (HIV-) and HIV+ homosexual men.

\section{Materials and methods}

Archived serum samples from the Los Angeles site of the MACS were obtained from 172 long-term HIV+

\footnotetext{
*Correspondence: ebreen@mednet.ucla.edu

'David Geffen School of Medicine, University of California, Los Angeles, Los Angeles, CA, USA

Full list of author information is available at the end of the article
}

(8.1-18 years), HAART-naive subjects at the latest visit before initiating HAART, and from 166 HIV- subjects of similar age (31-62 years) and ethnicity ( $88 \%$ White, $8 \%$ Hispanic, 2\% Black). Serum protein electrophoresis and quantitative IgG, IgM, IgA, kappa FLC, and lambda FLC assays were performed on all samples, followed by immunofixation when possible monoclonal protein or abnormal kappa/lambda FLC ratios were observed.

\section{Results}

Increased mean serum concentrations of IgG, IgA, IgM, kappa FLC, and lambda FLC $(\mathrm{p}<0.001)$ were seen in HIV+ subjects compared to HIV- subjects. Kappa/ lambda FLC ratios were higher in HIV+ men (1.16 vs. $1.04, \mathrm{p}<0.01)$, with a clear increase in the frequency of elevated ( $>1.65)$ ratios $(11.0 \%$ vs. $1.8 \%)$. MGUS prevalence (defined as a monoclonal peak confirmed by immunofixation) was $0 / 166(<0.6 \%)$ in HIV- and $4 / 172$ $(2.3 \%, \mathrm{p}<0.05)$ in HIV+ MACS subjects.

\section{Conclusions}

MGUS is uncommon but increased among untreated HIV+ MACS subjects under 65 years of age. FLC levels and/or abnormal ratios may be more sensitive indicator (s) of Ig abnormalities associated with MGUS or MM. Longitudinal MACS studies are planned to examine FLC, MGUS, and B cell activation.

\section{Acknowledgements}

This article has been published as part of Infectious Agents and Cancer Volume 5 Supplement 1, 2010: Proceedings of the $12^{\text {th }}$ International Conference on Malignancies in AIDS and Other Acquired Immunodeficiencies (ICMAOI). The full contents of the supplement are available online at http://www.biomedcentral.com/1750-9378/5?issue=S1. 


\section{Author details}

'David Geffen School of Medicine, University of California, Los Angeles, Los Angeles, CA, USA. ${ }^{2}$ Department of Laboratory Medicine and Pathology, Mayo Clinic, Rochester, MN, USA. ${ }^{3}$ School of Public Health, University of California, Los Angeles, Los Angeles, CA, USA.

Published: 11 October 2010

doi:10.1186/1750-9378-5-S1-A38

Cite this article as: Breen et al:: Immunoglobulin abnormalities and monoclonal gammopathy of undetermined significance in uninfected and HIV-infected men. Infectious Agents and Cancer 2010 5(Suppl 1):A38.

Submit your next manuscript to BioMed Central and take full advantage of:

- Convenient online submission

- Thorough peer review

- No space constraints or color figure charges

- Immediate publication on acceptance

- Inclusion in PubMed, CAS, Scopus and Google Scholar

- Research which is freely available for redistribution

Submit your manuscript at www.biomedcentral.com/submit 